$\mathbb{T}$ periodica polytechnica

\author{
Transportation Engineering \\ $39 / 1(2011) 7710$ \\ doi: 10.3311/pp.tr.2011-1.02 \\ web: http://www.pp.bme.hu/tr \\ (C) Periodica Polytechnica 2011
}

RESEARCH ARTICLE

\section{The mathematical modeling of reversible lane system}

\author{
Zsuzsanna Bede / Tamás Péter
}

Received 2010-10-27

\begin{abstract}
We examine the modeling of reversible lane system configured on a road part network. The functions of the each network's elements and contacts between its each element cease in the course of a change and new contacts and new function elements are activated instead of them. This opens the door to a new principled optimal control, which happens to the dynamic change of the structure of the network graph. In the model, as in reality, the geometry elements do not disappear naturally, but create a variable network as a result of their new function and their connection system. The article presents the mathematical modeling of the problem. Points out the fundamental questions of the structure change and exemplifies the above on a simple example.
\end{abstract}

\section{Keywords}

Reversible lane $\cdot$ road traffic control $\cdot$ mathematical modeling

\section{Acknowledgement}

The project presented in this article is supported by OTKA CNK 78168.

This work is connected to the scientific program of the "Development of quality-oriented and harmonized $R+D+I$ strategy and functional model at BME" project. This project is supported by the New Hungary Development Plan (Project ID: TÁMOP4.2.1/B-09/1/KMR-2010-0002 ).

\section{Zsuzsanna Bede}

Department of Control and Transport Automation, BME, Bertalan L. u. 2., H1111 Budapest, Hungary

e-mail: bede.zsuzsanna@mail.bme.hu

\section{Tamás Péter}

Department of Control and Transport Automation, BME, Bertalan L. u. 2., H1111 Budapest, Hungary

e-mail: tamas.peter@mail.bme.hu

\section{Introduction}

The application of reversible lane systems - RLS is an interesting special method, which favors maximally the change (part of the day, seasonally etc.) of primary current on the available road surface [1-9]. A number of estimations justifies the reduction of the travel time by about $40 \%$, the waiting time by about $50 \%$ and the number of the stops by circa $40 \%$ on those part networks, where this was introduced comparing to the original data. The effect of these traffic data reduces the accident indirectly, too, but it is necessary to analyze the risk factors, which occur in the course of the application of RLS [2].

\section{The mathematical model applied to this problem's solution}

Our method defines a dynamic contact structure consisting of $n$ parts inner sections and $m$ part exterior sections. Our network model position in province, which is delimited with a closed curve. In this case the vehicle densities in inner network are the state parameters of the system: $x=$ $\left[x_{1}(t), x_{2}(t), x_{3}(t), \ldots, x_{n}(t)\right]^{T}$. The vehicle densities in the exterior part network of network (which have a direct connection with some sections) are marked $s=\left[s_{1}(t), s_{2}(t), \ldots, s_{m}(t)\right]^{T}$, that we measure [10], [11], [12].

This mathematical model leads to the examination of the positive, non-linear (NL) dynamic system. The model functionally is a macroscopic model [13], [14], [15].

$$
x^{\prime}=\langle L\rangle^{-1}\left[K(x, s) x+K_{\text {input }}(x, s) s\right]
$$

Where: $\langle L\rangle^{-1}$ diagonal matrix contains the reciprocal of inner section lengths. $K(x, s)$ constructed matrix, which was constituted of $K_{\text {inner }}(x, s)$ and $K_{\text {output }}(x, s)$ matrix. The elements of $K(x, s)$ and $K_{\text {input }}(x, s)$ connection matrices are the connection functions, which depend on the density states. The physical meaning of the matrix's elements is the passing speed. The system is a positive system. 


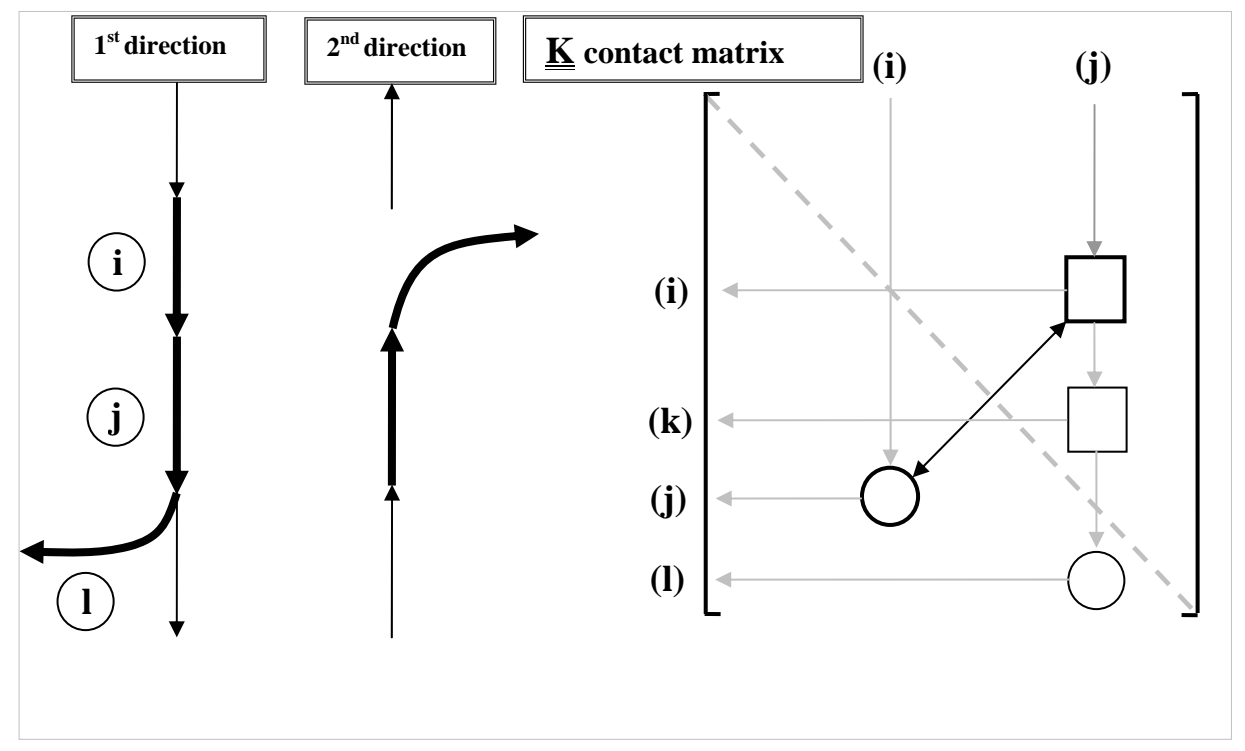

Fig. 1. Two traffic directions and the contact matrix

\section{The contact matrix of Reversible Lanes System, con- trol signs and state parameters}

There are two traffic directions on the left side of Fig. 1], where we consider the contacts of the sections nominated thickly. We labeled the examined sections with a circle in case of 1 . direction and with a square in case of 2. direction. We may establish, that two kinds of contact forms exist:

I Constant geometry contact: so contact of $\mathrm{i}$ and $\mathrm{j}$. In this case the geometry contact remains in all traffic direction change, but what changes is the direction of the passing (in case of 1 . direction: $i \rightarrow j$, in case of 2 . direction: $j \rightarrow i$ ).

II Contact depending on direction: so in case of the 1. direction contact of $j$ and $l$, in case of the 2 . direction contact of $j$ and $k$. In this case the geometry contact depends on the traffic direction (in case of 1 . direction: $j \rightarrow l$, in case of 2. direction: $j \rightarrow k)$.

Two things must be enhanced: the contact between $i$ and $j$ elements and the direction of this passing. (Ex.: $\mathrm{K}_{i, j}$ element, if not equivalently 0 , shows that there is a contact and that $j$ works onto $i: j \rightarrow i$ ).

- All such contacts remain invariant in the contact matrix, which does not affect the direction change!

- The contacts, which are affected by the direction change, the contacts connected to 1 . and 2. direction close one another off! So, in the contact matrix, the contact may appear, which is marked only with a square or with a circle in a certain time.

- In case of a constant geometry contact: The contact is reflected onto a main diagonal as a result of the direction change $(\mathrm{i}, \mathrm{j}) \leftrightarrow(\mathrm{j}, \mathrm{i})$.

- There is no reflection in case of the contact connected to only a single direction. This contact appears in only one direction. Ex. $(j \rightarrow k)$.

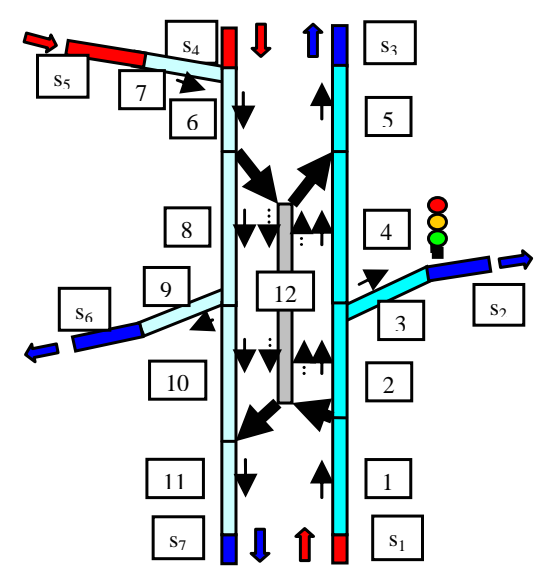

Fig. 2. Sample model, on model of reversible lanes system

- Finally this is very important, that the contact change does not happen at the same time in the contact matrix. The dissociation of the contacts happens in two steps.

\section{Example the model of Reversible Lanes System}

Our model is NL positive system with 12 degrees of freedom, 7 exterior contacts where:

- $s_{1}, s_{4}, s_{5}$ are measured inputs, $s_{2}, s_{3}, s_{6}, s_{7}$ are measured outputs, with $p_{1}, p_{2}, \ldots, p_{7}$ section lengths.

- $1,2, \ldots, 11$ are network sections characterized with $x_{1}$, $x_{2}, \ldots, x_{11}$ state parameters and with $l_{1}, l_{2}, \ldots, l_{11}$ section lengths.

- 12 is reversible lane in both directions marked with $x_{12}$ state parameter and with $l_{12}$ section length.

Let us assume that:

- A morning peak is evolved in the section directed upwards from below. Section 3 often gets a red light as a result of the crossing railway traffic, because of this the section 2 and 1 get blocked. 
- An afternoon peak is evolved in the section directed upsidedown. At this time the vehicle density of section $s_{6}$ is overloaded, because of this section 9 often gets blocked as a result of this 8 , too, and this influences 6 and onto 7 !

We mark obstruction $\beta_{i j}$ with passing through $j$ to $i(j \rightarrow i)$. Obstruction appears between the sections below, at the right side sections in the model:

$\beta_{2,1}:(1 \rightarrow 2), \beta_{3,2}:(2 \rightarrow 3), \beta_{4,2}:(2 \rightarrow 4), \beta_{5,4}:(4 \rightarrow 5)$

and at the left side sections:

$$
\begin{gathered}
\beta_{8,6}:(6 \rightarrow 8), \beta_{9,8}: \\
(8 \rightarrow 9), \beta_{10,8}:(8 \rightarrow 10), \beta_{11,10}:(10 \rightarrow 11) .
\end{gathered}
$$

We mark distribution rate $\alpha_{i j}$ with passing through $j$ to $i$ $(j \rightarrow i)$. A distribution rate appears between the sections below, at the right side sections in the model:

$\alpha_{12,1}:(1 \rightarrow 12), \alpha_{2,1}:(1 \rightarrow 2)$, where $: \quad \alpha_{2,1}=1-\alpha_{12,1}$

If we do not use section $12 \alpha_{12,1}=0$, and $\alpha_{2,1}=1$, if we use it we have established a $\alpha_{12,1}=0.45$ rate, and at this time $\alpha_{2,1}=$ 0.55 .

The survey of the rate is interestingly formed with the $2 \rightarrow 3$ transition. Let this be $\alpha_{32}:(2 \rightarrow 3)$, if we do not use section 12 , so this means, that being in the section 2 wish to turn right in the above ratio. These drivers wish to turn right here when the section 12 works, because this is their route in the morning peak. The number of drivers in the section 2 decrease by working of section 12 , according to a $\alpha_{2,1}$ factor.

Because of this transition from 2 onto 3: it is necessary to count with a $\frac{\alpha_{3,2}}{\alpha_{2,1}}:(2 \rightarrow 3)$ rate, respectively, if we count with $\alpha_{12,1}$ in all cases, the transition from 2 onto $4: \frac{\alpha_{3,2}}{1-\alpha_{12,1}}:(2 \rightarrow 3)$ and $1-\frac{\alpha_{3,2}}{1-\alpha_{12,1}}:(2 \rightarrow 4)$.

The same happens to the inscription of the distribution rates with the vehicles travelling from the other direction.

\section{Computational results onto the model of Reversible Lane System}

At first we did the examinations on the breakfast and the afternoon peaks without section 12 . In the second case we did the examinations with an already operating reversible lane. The results on the figures below are received on a 20 minute time interval. We see the percental growth rate of the number of all crossing vehicles until timepoint $t$, and the same with activated reversible lane on Figs. 3 and 4 .

The results show, that the growths are $20 \%$ in the morning peak and $30 \%$ in the afternoon peak for the full model's case. This resulted $26 \%$ growth for the whole day (Fig. 4).

In the morning peak the vehicle density decreases with activated reversible lane (left side). The speed increment in $\mathrm{m} / \mathrm{sec}$
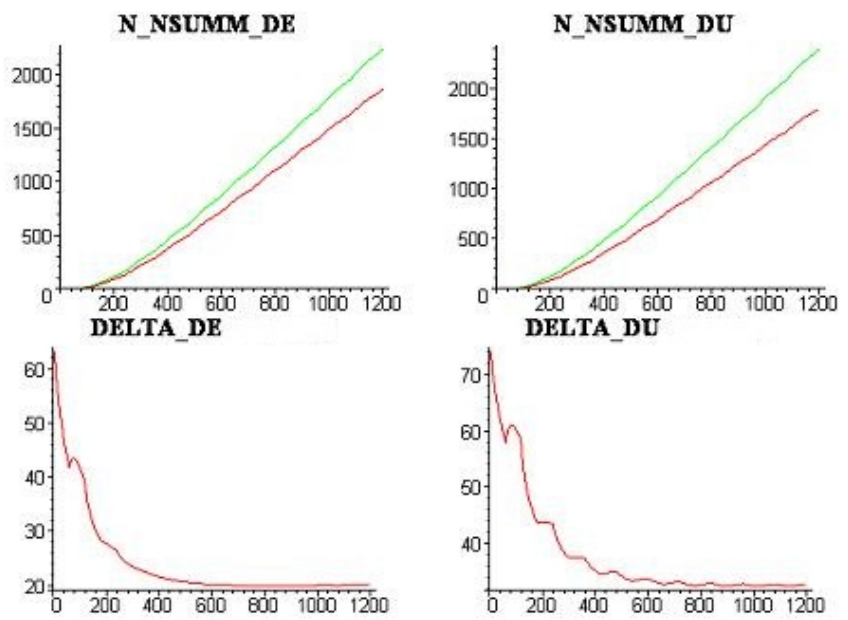

Fig. 3. The number of passing vehicles separated for the morning (DE) and for the afternoon (DU) peaks including percentile growths, with the reversible lane being activated

[the horizontal axis contains the time $\mathrm{t}$ [sec], the vertical axis contains the number of vehicles, the lower diagrams are in percent [\%]]

\section{DELTA}

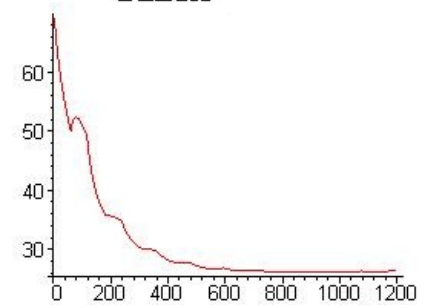

Fig. 4. Band accomplished (morning and afternoon) percental growths, with the reversible lane being activated

[horizontal axis contains the time $t$ [sec], the vertical axis is percent [\%]]

(right side) and the percentile improvements can be seen on sections 1,2 , and 4 of Figs. 1 , 3 .

These functions were critical in the original system. It it noticeable, that the traffic density on these sections reduced with $25 \%, 33 \%, 87 \%$, though the speed of the traffic has grown with $50 \%, 48 \%, 12 \%$ on the same sections.
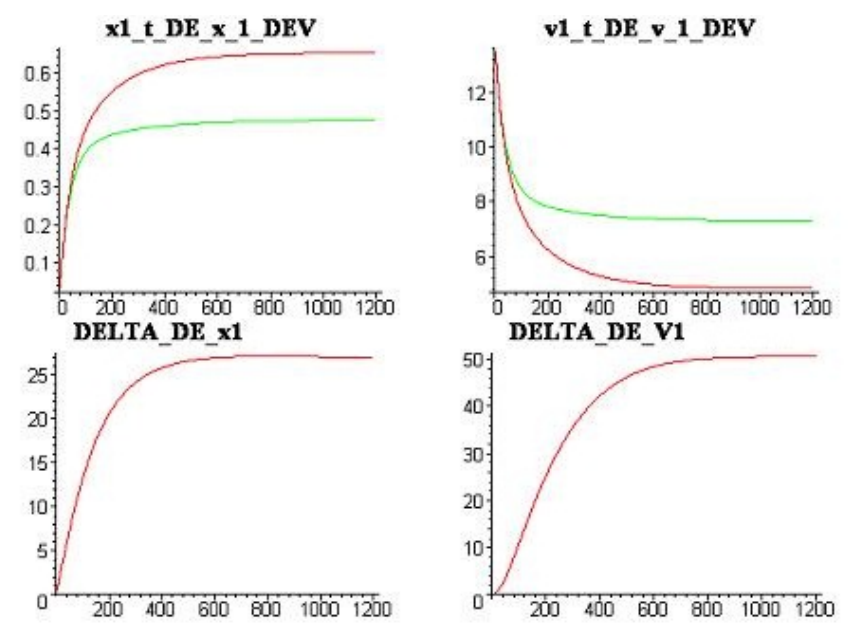

Fig. 5. The percental improvement of vehicle density caused decrease in the morning peak (on the left side) and speed increment (right side) with the reversible lane being activated on the 1 section. 

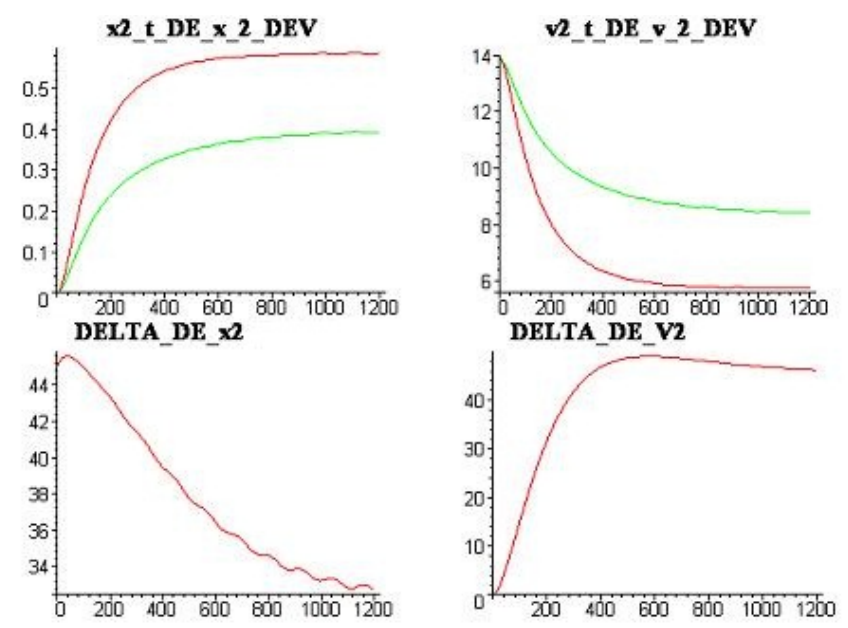

Fig. 6. The percental improvement of vehicle density caused decrease in the morning peak (on the left side) and speed increment (right side) with the reversible lane being activated on the 2 section.
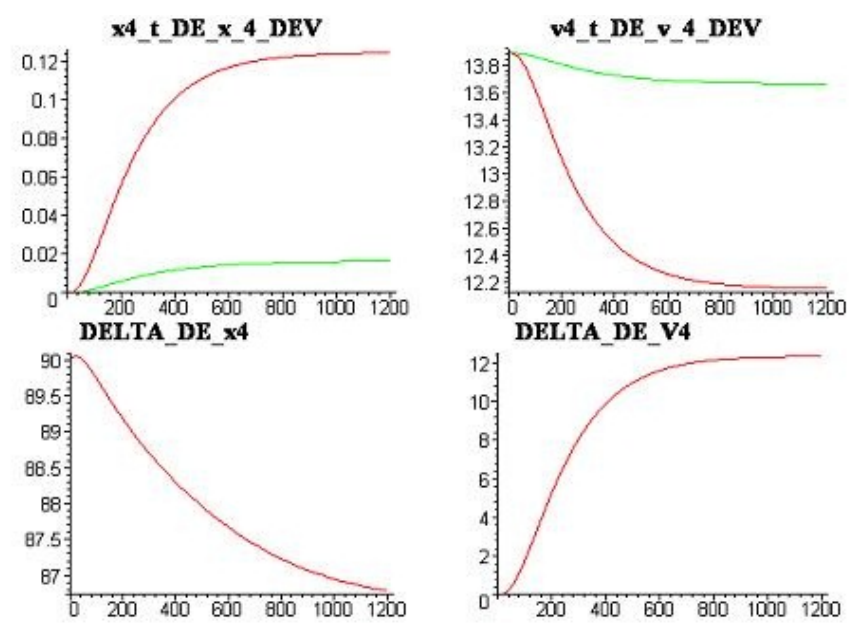

Fig. 7. The percental improvement of vehicle density caused decrease in the morning peak (on the left side) and speed increment (right side) with the reversible lane being activated on the 4 section.

\section{Summary}

We examined a general mathematical model describing the Reversible Lane System. Our descriptive mathematical network model is a positive non-linear dynamic system, and also important that it is a macroscopic model. The function of every element and the contacts between the elements cease in case of direction change in any part of the network, then new contacts and new functional elements are activated. We examined the availability of the optimal control in a sample network depending on the traffic density, using a new principle, which responses to the dynamic change of the structure of the network graph. It can be shown, that the results from our model are in harmony with the real traffic values based on measurements made in road traffic systems working with Reversible Lane System, included in our literature references.

\section{References}

1 Bede Zs, Péter T, A változtatható irányú forgalmi sávok hazai alkalmazásának aktualitása, egy lehetôség, a közúti forgalom optimálására, Közlekedéstudományi Szemle 59 (2009 április), no. 2, 21-36.

2 _ A változtatható irányú forgalmi sávok alkalmazása során fellépó kockázati tényezók elemzése, Városi Közlekedés 49 (2009 december), no. 6, 326-332.

3 Fisher J E, Transportation Topics and Tales: Milestones in Transportation History in Southern California.

4 Wolshon B, Lambert L, Reversible Lane Systems: Synthesis of Practice, December, 2006.

5 HOV/Managed Lanes/Ramp Metering Design Manual., Nevada Department of Transportation.

6 Barrier Systems Inc., Sávelválasztó elemek termékismertetóje, available at http://: www.barriersystemsinc.com

7 Managed Lanes Handbook, Texas Transportation Institute, October, 2005. The Texas A\&M University System, Report 0-4160-24.

8 PARSONS BRINCKERHOFF QUADE \& DOUGLAS INC., State Route 75 and State Route 282 Transportation Corridor Major Investment Study (MIS) Task 5.0, 2003. Summary Report September 16.

9 TDOT: City of Tucson Department of Transportation publication: Grant Road Reversible Lane facts, April, 2004, available at http://dot. tucsonaz.gov/news

10 Péter T, Bokor J, Jármúforgalmi rendszerek modellezése és irányításának kutatása, A jövő jármúve 06, no. 1-2, 19-23.

11 _ Nagy méretú közúti közlekedési hálózatok nemlineáris modelljének kapcsolati hipermátrixa, A jövő jármúve (2007).

12 Péter T, Nagyméretú nemlineáris közlekedési hálózatok modellezése, Közlekedéstudományi Szemle 57 (2007), no. 9, 322-331.

13 _ Tetszóleges méretü nemlineáris közúti közlekedési hálózatok modellezése speciális hálózati gráffal, amelyben a gráf csúcsai általánosított szakaszok, a gráf élei a csúcsok közötti kooperálót leíró dinamikus relációk, A jövő jármúve 3 (2008), no. 3-4, 26-29.

14 Péter T, Stróbl A, Fazekas S, Szoftverfejlesztés eredményei, a nagyméretü közúti közlekedési hálózatok analízisére és tervezésére, A jövő jármúve $\mathbf{3}$ (2008), no. 3-4, 30-33.

15 Péter T, Jármúforgalmi rendszerek modellezése és irányítása, célok, kutatási területek és eredmények, A jövő jármúve 4 (2009), no. 1-2, 59-78. 